\title{
The ceiling effect of curcumin and quercetin in combination on cyclophosphamide induced hepatotoxicity
}

\author{
Manoj Kumar Yadav**, Jayesh Dwivedi*, Prabhat Kumar Upadhyay** and Vishal Kumar Vishwakarma*** \\ Pacific Academy of Higher Education and Research University, Udaipur-313024, Rajasthan, India \\ **Institute of Pharmaceutical Research, GLA University, Mathura-281406, Uttar Pradesh, India \\ ***Department of Pharmacology, All India Institute of Medical sciences, New Delhi-110029, India
}

\section{Article Info}

Article history

Received 10 March 2021

Revised 28 April 2021

Accepted 30 April 2021

Published online 30 June 2021

\section{Keywords}

Quercetin

Curcumin

Hepatotoxicity

Cyclophosphamide

Histopathology

\begin{abstract}
An alkylating agent named cyclophosphamide (CP) is an immunosuppressant used in therapy of rheumatoid arthritis and a variety of cancers. The combination of curcumin and quercetin was evaluated for antioxidant activity against the CP-induced hepatotoxicity in Wistar rats. A prophylactic treatment using combination of curcumin and quercetin is given at $80 \mathrm{mg} / \mathrm{kg}$ and $200 \mathrm{mg} / \mathrm{kg}$ (b.w.) of oral dose to the rats before administering single injection of $\mathrm{CP}$ at $200 \mathrm{mg} / \mathrm{kg}$ intra-peritoneally (i.p.). The effects of curcumin and quercetin combination on $\mathrm{CP}$-induced hepatotoxicity were investigated using oxidative stress, serum liver toxicity markers, and histopathology of liver tissue examination. A single dose of CP administered i.p. and enhances the malondialdehyde level whereas reduces the glutathione content in the rat. The administration of curcumin and quercetin at specific doses could cause substantial reduction in the levels in plasma concentration. Therefore, the action of antioxidant enzymes restores. The marker enzymes producing serum toxicity like SGPT, SGOT, serum alkaline phosphatase level increased after CP treatment which was considerably decreased in curcumin and quercetin pretreated groups. Present findings suggest that curcumin and quercetin combination has prominent role against $\mathrm{CP}$ induced liver injury.
\end{abstract}

\section{Introduction}

Hepatotoxicity is a condition that affects the liver. The cyclophosphamide (CP) is used to treat $43 \%$ cancer patients with mild and recurrent increase in serum aminotransferase levels. The anomalies are usually asymptomatic and temporary, so no dosage adjustments are necessary. Higher doses and intravenous treatment are more likely to cause enzyme elevations (Subramaniam et al., 2013). The clinically visible liver damage from standard cyclophosphamide doses is rare, whereas some cases of acute liver damage associated with jaundice have been reported. The beginning occurs within 2 to 8 weeks of cyclophosphamide treatment and cause elevations in the serum enzyme in the hepatocellular structure. The autoimmune and immunoallergic manifestations are rare (Grigorian and O'Brien, 2014).

The fatal cases have been recorded and resolves within 1 to 3 months of stopping; however, fatal cases have been reported. The administration of cyclophosphamide with high doses in the cancer chemotherapy causes sinusoidal obstruction syndrome in conjunction with total body irradiation. In hematopoietic cellular transplantation, busulfanis generally used in anticancer preparation (Liver Tox, 2019).

Corresponding author: Mr. Manoj Kumar Yadav Pacific Academy of Higher Education and Research University Udaipur-313024, Rajasthan, India

E-mail: dsmanojyadav@yahoo.com

Tel.: +91-9319018812

Copyright (c) 2021 Ukaaz Publications. All rights reserved.

Email: ukaaz@yahoo.com; Website: www.ukaazpublications.com
The injury usually occurs within 10 to 20 days of myeloablation. It is characterized by ascites, weight gain, abdominal pain, hepatic dysfunction and jaundice. The levels of serum aminotransferase become increased in such injury. Sinusoidal obstruction syndrome can range from small self-limited injury to acute liver failure. The ascites, weight gain, jaundice and enlargement of the liver are commonly used for the diagnosis. Because of serious thrombocytopenia following hematopoietic cell transplantation, liver biopsy is frequently contraindicated (Liver Tox, 2019).

Curcumin is well known natural product which was used from thousands of years. Curcumin (Diferuloyl methane) belonging to family Zingiberaceae and considered as polyphenol present in the perennial herb, turmeric (Curcuma longa). A variety of activities have reported in curcumin including anti-inflammatory and antioxidant. Antioxidant power represents an ability to reduce the formation of reactive oxygen species (ROS) (Biswas et al., 2005). It has been reported that curcumin showed antioxidant properties in the cell line of kidney and revolutionized ferric nitrilo-triacetic acid (Fe-NTA) mediated oxidative stress in the kidney of mice (Cohly et $a l ., 1998)$. A variety of antioxidant actions of curcumin have been reported in many research papers. Therefore, curcumin is powerful scavenger of various reactive oxygen species including hydroxyl radicals, superoxide anion radicals and cause the reduction in the lipid peroxidation (Okada, 2001; Sreejayan and Rao, 1994).

In this study, an attempt has been made to examine the important actions of curcumin combined with quercetin against $\mathrm{CP}$-induced hepatotoxicity. Moreover, the biochemical assessment of antioxi- 
dant enzymes and histopathological measurement would be done to determine the role of oxidative stress against hepatotoxicity.

\section{Materials and Methods}

\subsection{Drugs}

Cyclophosphamide and curcumin was procured from Sigma-Aldrich Fine Chemicals. Quercetin were purchased from Hi Media Laboratories Pvt. Ltd, Mumbai.

\subsection{Animals}

Male Wistar rats (250-300 g) were kept under conditions of controlled temperature $\left(22 \pm 2^{\circ} \mathrm{C}\right)$ and acclimatized to $12 / 12 \mathrm{~h}$ light/dark cycle. The animals were kept in polypropylene cages at a temperature of relative humidity $(50 \pm 5 \%)$. They were fed with standard laboratory animal diet and water ad libitum. Animals were acclimatized to laboratory conditions before the test and randomly selected animals marked to permit individual identification were kept in clean polypropylene cages for 5 days prior to start an experiment. This study was approved by Institutional Animal Ethical Committee from CPCSEA (1622/PO/Re/S/12/CPCSEA), New Delhi.

\subsubsection{Acute toxicity assay}

The oral acute toxicity study of curcumin + quercetin combination was evaluated according to Organization for Economic Cooperation and Development (OECD) guideline 423 (OECD 2001). Oral administration of curcumin + quercetin combination at a dose of $2000 \mathrm{mg} / \mathrm{kg}$ bodyweight did not produce any mortality or adverse effects during the 14 days' period of study and also observed no abnormal clinical signs. The body weight and food consumption were also remaining unchanged, when compared to the untreated control group of animals.

\subsection{Drug treatment}

Group 1 (Control) administered with saline. Group 2 administered with $\mathrm{CP}$ at $200 \mathrm{mg} / \mathrm{kg}$ single dose i.p on day 1 . Groups 3 and 4 administered with single dose of CP $(200 \mathrm{mg} / \mathrm{kg})$ i.p. on day 1 and treated with curcumin $80 \mathrm{mg} / \mathrm{kg}$ and $200 \mathrm{mg} / \mathrm{kg}$ for 14 days, respectively. The rats in Group 5 administered with combination of CP $(200 \mathrm{mg} / \mathrm{kg}$, i.p. $)$, curcumin and quercetin $(80 \mathrm{mg} / \mathrm{kg}+200$ $\mathrm{mg} / \mathrm{kg}$, oral). Thirty animals were divided equally into five groups $(n=6)$. Group I: Naive controls (Saline, orally), Group II: CP (200 $\mathrm{mg} / \mathrm{kg}$, i.p. $)$, Group III: CP (200 mg/kg, i.p. $)+$ curcumin $(80 \mathrm{mg} / \mathrm{kg}$, oral), Group IV: CP (200 mg/kg, i.p. $)+$ quercetin $(200 \mathrm{mg} / \mathrm{kg}$, orally), Group V: CP (200 mg/kg, i.p. $)+$ curcumin + quercetin $(80 \mathrm{mg} / \mathrm{kg}+$ $200 \mathrm{mg} / \mathrm{kg}$ respectively, and orally).

\subsection{Hematological evaluation in blood}

The hematological variables, viz., $\mathrm{RBC}, \mathrm{WBC}$, and $\mathrm{Hb}$ were measured by standard procedures (Dal'Bó et al., 2015).

\subsection{Serum marker enzymes evaluation}

The glutamic oxaloacetic transaminase (SGOT), serum glutamic pyruvate transaminase (SGPT), total bilirubin, alkaline phosphatase (ALP), and total protein concentration were estimated using commercially available kits (E-coline, Merck, India) as per manufacturer's instructions.

\subsection{Assay for MDA}

The trichloro acetic acid ( $1 \mathrm{ml}$ of $20 \%$ TCA), thiobarbituric acid (1 $\mathrm{ml}$ of $0.67 \% \mathrm{TBA})$, and serum $(100 \mu \mathrm{l})$ were incubated at $100^{\circ} \mathrm{C}$ for about $20 \mathrm{~min}$ and then centrifuged for $5 \mathrm{~min}$ at $12,000 \mathrm{rpm}$. The absorbance of the supernatant was measured at $532 \mathrm{~nm}$. The concentration of MDA was calculated using a molar extinction coefficient of $1.56 \times 10^{5} / \mathrm{M} / \mathrm{cm}$ and expressed in $\mathrm{mM}$ (Siddiqui et al., 2010).

A part of the liver was used for biochemical prediction in the lipid peroxidation assay. The amount of MDA in the liver was measured using the Ohkawa et al. (1979) procedure to check lipid peroxidation. $2 \mathrm{ml}$ of suspension medium was centrifuged at 10,000 rpm from the supernatants of the $10 \%$ tissue homogenate in 1.15 per cent $\mathrm{KCl} .1 \mathrm{ml}$ of 30 per cent TCA was applied to it, followed by adding $1 \mathrm{ml}$ of 0.8 per cent TBA.

The aluminum foil was used to wrap the tubes. The tubes were placed in a trembling water bath at $800^{\circ} \mathrm{C}$ for $30 \mathrm{~min}$. After that, the tubes were placed in the ice cold water for $10 \mathrm{~min}$ and centrifuged for $15 \mathrm{~min}$ at $3000 \mathrm{rpm}$. The absorbance of the supernatant was measured against a blank at $540 \mathrm{~nm}$ at the room temperature. $2 \mathrm{ml}$ distilled water, $1 \mathrm{ml} \mathrm{TBA}$, and $1 \mathrm{ml}$ TCA were used to make up the blank (Siddiqui et al., 2010).

\subsection{Assay for glutathione}

Tissue GSH was measured using Sedlak and Lindsay's procedure (1968). A part of the reperfused liver tissue (300-600 mg) was homogenised in 5-8 $\mathrm{ml}$ of $0.02 \mathrm{M}$ EDTA before being applied to 4 $\mathrm{ml}$ of cold distilled water. After mixing, $1 \mathrm{ml}$ of $50 \%$ TCA was added and shaken for $10 \mathrm{~min}$ before centrifuging at $6000 \mathrm{rpm}$ for $15 \mathrm{~min} .4$ $\mathrm{ml}$ of $0.4 \mathrm{M}$ tris buffer, $2 \mathrm{ml}$ of supernatant, and $0.1 \mathrm{ml} 0.01 \mathrm{M}$ DTNB were combined. At room temperature, the absorbance of the resultant mixture was measured at $410 \mathrm{~nm}$ against a blank (Sedlak et al., 1968; Thiruvengadam et al., 2006).

\subsection{Oxidized glutathione (GSSG) assay}

The low concentration of GSSG in tissues (high GSH/GSSG ratio) may stop GSH oxidation. In sample preparation, correct calculation of GSSG is significant factors to stop such oxidation. In this, NEthylmaleimide (NEM) reacts with GSH to form a stable compound and eliminates GSH before the quantification of GSSG in tissues which was first reported by Guntherberg and Rost, (1966). Sedlak and Lindsay's procedure was also used to measure tissue GSSG (Sedlak et al., 1968; Thiruvengadam et al., 2006).

\subsection{Organ to body weight indices (OBWI)}

Once, the animals have been slaughtered, the liver will be removed, cleaned, and measured. The following formula will be used to measure the organ to body weight indices (OBWI):

$$
\text { OBWI }=\frac{\text { Organ weight }}{\text { Body weight }} \times 100
$$

\subsubsection{Histopathological study}

Small blocks of tissues were taken from the organs (liver) harvested from the rats and processed using an automated tissue processor. After processing, the tissues were sectioned to a thickness of $5 \mu \mathrm{m}$, 
using a rotary microtome and dried overnight in an oven at $37^{\circ} \mathrm{C}$. The sections were stained with hematoxylin and eosin (H\&E). For microscopic examination, tissue sections were placed on glass slides and examined by a blinded pathologist. The images were captured by an Olympus DP71 camera (Brown and Kleiner, 2016).

\subsection{Statistical analysis}

Statistical evaluations were carried out using one-way ANOVA, followed by Dunnet's exam. Statistical significance was defined as a probability of $p \geq 0.05$ or less. SPSS 16.0 was used to perform this study.

\section{Results}

\subsection{Organ to body weight indices}

The organ bodyweight indices of the various classes of rats are given in Table 1. In comparison to Group I, the OBWI of cyclophosphamide-induced Group II rats have increased. Curcumin and curcumin + quercetin were administered to Groups III, IV, and $\mathrm{V}$ rats for 14 days, and the OBWI was almost back to normal. When comparing Group IV to Group II, the gain in body weight could be due to the regeneration of liver cells to near normal after the herbal therapy.

Table 1: Effects of curcumin andcurcumin+quercetin on body weight, wet liver weight and obwi of different animal groups

\begin{tabular}{|c|l|l|c|c|c|}
\hline SI.No. & Groups & Treatment given & $\begin{array}{c}\text { Body weight } \\
\text { (gms) } \\
\text { Mean } \pm \text { SEM }\end{array}$ & $\begin{array}{c}\text { Wet liver } \\
\text { weight }(\text { gms }) \\
\text { Mean } \pm \text { SEM }\end{array}$ & $\begin{array}{c}\text { Ob wi } \\
\text { Mean } \pm \text { SEM }\end{array}$ \\
\hline 1. & Naive control & Saline, oral & $200 \pm 2.03$ & $5.26 \pm 0.04$ & $2.63 \pm 0.012$ \\
\hline 2. & Disease control & CP $(200 \mathrm{mg} / \mathrm{kg}$, i.p) & $210 \pm 3.44$ & $9.74 \pm 00.7$ & $4.70 \pm 0.030$ \\
\hline 3. & Test drug dose I & $\begin{array}{l}\text { CP }(200 \mathrm{mg} / \mathrm{kg}, \text { i.p. })+\text { Curcumin } \\
(80 \mathrm{mg} / \mathrm{kg}, \text { oral })\end{array}$ & $200 \pm 2.03^{*}$ & $6.90 \pm 0.57^{*}$ & $3.45 \pm 0.017 *$ \\
\hline 4. & Test drug dose II & $\begin{array}{l}\text { CP }(200 \mathrm{mg} / \mathrm{kg}, \text { i.p. })+\text { Quercetin } \\
(200 \mathrm{mg} / \mathrm{kg}, \text { oral })\end{array}$ & $210 \pm 3.44^{*}$ & $6.30 \pm 053^{*}$ & $3.00 \pm 0.016^{*}$ \\
\hline 5. & Standard drug & $\begin{array}{l}\text { CP }(200 \mathrm{mg} / \mathrm{kg}, \text { i.p. })+\text { Curcumin }+ \\
\text { Quercetin }(80 \mathrm{mg} / \mathrm{kg}+200 \mathrm{mg} / \mathrm{kg}, \text { oral })\end{array}$ & $205 \pm 1.23^{*}$ & $5.86 \pm 0.41^{*}$ & $2.85 \pm 0.013^{*}$ \\
\hline
\end{tabular}

Statistically significance test was done by One-Way ANOVA followed by Dunnett's ' $t$ ' test using SPSS 16.0 Windows version. * $p<0.05$ compared to disease control group.

Table 2: Effects of Curcumin and curcumin + quercetin on hematology of different animal groups

\begin{tabular}{|c|l|l|c|c|c|}
\hline SI.No. & Groups & Treatment given & $\begin{array}{c}\text { Hb } \\
\text { levels } \text { (gm \%) } \\
\text { Mean } \pm \text { SEM }\end{array}$ & $\begin{array}{c}\text { RBCs } \\
\text { levels } \\
(\mathbf{m i l l i o n} / \mathbf{c m m}) \\
\text { Mean } \pm \text { SEM }\end{array}$ & $\begin{array}{c}\text { WBCs } \\
\text { levels } \\
\text { (Per cmm) } \\
\text { Mean } \pm \text { SEM }\end{array}$ \\
\hline 1 & Naive control & Saline, oral & $13.3 \pm 0.53$ & $4.44 \pm 0.13$ & $7250 \pm 1.15$ \\
\hline 2 & Disease control & CP $(200 \mathrm{mg} / \mathrm{kg}$, i.p) & $9.49 \pm 0.32$ & $2.91 . \pm 0.11$ & $14456 \pm 1.53$ \\
\hline 3 & Test drug dose I & $\begin{array}{l}\text { CP }(200 \mathrm{mg} / \mathrm{kg}, \text { i.p. })+\text { Curcumin } \\
(80 \mathrm{mg} / \mathrm{kg}, \text { oral })\end{array}$ & $10.4 \pm 0.30^{*}$ & $3.37 . \pm 0.15^{*}$ & $9441 \pm 0.21^{*}$ \\
\hline 4 & Test drug dose II & $\begin{array}{l}\text { CP }(200 \mathrm{mg} / \mathrm{kg}, \mathrm{i} . \mathrm{p} .)+\text { Quercetin } \\
(200 \mathrm{mg} / \mathrm{kg}, \text { oral })\end{array}$ & $12.2 \pm 0.32^{*}$ & $4.16 \pm 0.14^{*}$ & $8142 \pm 1.31^{*}$ \\
\hline 5 & Standard drug & $\begin{array}{l}\text { CP }(200 \mathrm{mg} / \mathrm{kg}, \mathrm{i.p.})+\text { Curcumin }+ \\
\text { Quercetin }(80 \mathrm{mg} / \mathrm{kg}+200 \mathrm{mg} / \mathrm{kg}, \text { oral })\end{array}$ & $12.9 \pm 0.41^{*}$ & $4.24 \pm 0.15^{*}$ & $7993 \pm 1.40^{*}$ \\
\hline
\end{tabular}

Statistically significance test was done by One-Way ANOVA followed by Dennett's 't' test using SPSS 16.0 Windows version.

$* p<0.05$ compared to disease control group.

\subsection{Heamatological parameters}

Table 2 represents various heamatological parameters like $\mathrm{Hb}, \mathrm{RBC}$ count and WBC count of all groups. Treatment with curcumin, quercetin and curcumin and quercetin combination in test groups maintain the parameters near normal value.

\subsection{Biochemical evaluation in serum}

Table 3 represents that the CP has enhanced the levels of SGPT, SGOT, serum alkaline phosphatase level (SALP). The Table 4 represents the bilirubin (both total and direct bilirubin levels) which also increased by $\mathrm{CP}$ and significantly controlled by curcumin and curcumin + quercetin while, plasma proteins are decreased considerably. This clearly indicates that hepatic damage occurs due to cyclophosphamide. Treatment with curcumin and curcumin + quercetin have brought down the elevated SGOT, SGPT, SALP levels. The bilirubin also considerably enhanced the decreased levels of plasma proteins.

\subsection{Tissue MDA and serum MDA}

Table 5 represents that the level of lipid peroxidation (expressed as MDA) was significantly increased in the liver tissue of CP-treated group, compared to the control group. Treatment with curcumin and curcumin + quercetin, significantly reduced CP-induced increase of TBARS content. Serum MDA was significantly increased of CPtreated group, compared to the control group. Treatment with curcumin and curcumin + quercetin combination considerably reduced $\mathrm{CP}$ induced rise in serum MDA. 
Table 3: Effects of curcumin and curcumin + quercetin on SGPT, SGOT and ALP of different groups of animals

\begin{tabular}{|c|l|l|c|c|c|}
\hline SI.No. & Groups & Treatment given & $\begin{array}{c}\text { SGPT } \\
\text { levels (U/L) } \\
\text { Mean } \pm \text { SEM }\end{array}$ & $\begin{array}{c}\text { SGOT } \\
\text { levels } \\
\text { (U/L) } \\
\text { Mean } \pm \text { SEM }\end{array}$ & $\begin{array}{c}\text { ALP } \\
\text { levels } \\
\text { (U/L) } \\
\text { Mean } \pm \text { SEM }\end{array}$ \\
\hline 1. & Naive control & Saline, oral & $69.3 \pm 0.53$ & $113.04 \pm 0.56$ & $150.3 \pm 1.32$ \\
\hline 2. & Disease control & CP $(200 \mathrm{mg} / \mathrm{kg}$, i.p) & $135.49 \pm 0.32$ & $250.30 \pm 1.50$ & $463 \pm 0.13$ \\
\hline 3. & Test drug dose I & $\begin{array}{l}\text { CP }(200 \mathrm{mg} / \mathrm{kg}, \text { i.p. })+\text { Curcumin } \\
(80 \mathrm{mg} / \mathrm{kg}, \text { oral })\end{array}$ & $85.57 \pm 1.30^{*}$ & $175.20 \pm 1.30^{*}$ & $210.6 \pm 1.21^{*}$ \\
\hline 4. & Test drug dose II & $\begin{array}{l}\text { CP }(200 \mathrm{mg} / \mathrm{kg}, \text { i.p. })+\text { Quercetin } \\
(200 \mathrm{mg} / \mathrm{kg}, \text { oral })\end{array}$ & $78.53 \pm 0.32^{*}$ & $135.93 \pm 1.48^{*}$ & $174.4 \pm 1.10^{*}$ \\
\hline 5. & Test drug dose III & $\begin{array}{l}\text { CP(200 mg/kg, i.p. })+ \text { Curcumin }+ \text { Quercetin } \\
(80 \mathrm{mg} / \mathrm{kg}+200 \mathrm{mg} / \mathrm{kg}, \text { oral })\end{array}$ & $73.62 \pm 0.41^{*}$ & $122.04 \pm 0.48^{*}$ & $169.8 \pm 0.42^{*}$ \\
\hline
\end{tabular}

Statistically significance test was done by One-Way ANOVA followed by Dennett's 't' test using SPSS 16.0 Windows version. ${ }^{*} p<0.05$ compared to disease control group.

Table 4: Effects of curcumin and curcumin + quercetin on total bilirubin and total protein of different animal groups

\begin{tabular}{|c|l|l|c|c|}
\hline SI.No. & Groups & Treatment given & $\begin{array}{c}\text { Total bilirubin } \\
\text { levels }(\mathbf{m g} / \mathbf{d l}) \\
\text { Mean } \pm \text { SEM }\end{array}$ & $\begin{array}{c}\text { Total protein } \\
\text { levels }(\mathbf{m g} / \mathbf{d l}) \\
\text { Mean } \pm \text { SEM }\end{array}$ \\
\hline 1. & Naive control & Saline, oral & $0.68 \pm 0.004$ & $6.80 \pm 0.008$ \\
\hline 2. & Disease control & CP $(200 \mathrm{mg} / \mathrm{kg}$, i.p) & $1.43 \pm 0.003$ & $3.88 \pm 0.029$ \\
\hline 3. & Test drug dose I & CP $(200 \mathrm{mg} / \mathrm{kg}$, i.p. $)+$ Curcumin $(80 \mathrm{mg} / \mathrm{kg}$, oral $)$ & $0.90 \pm 0.01^{*}$ & $5.19 \pm 0.006^{*}$ \\
\hline 4. & Test drug dose II & CP $(200 \mathrm{mg} / \mathrm{kg}$, i.p. $)+$ Quercetin $(200 \mathrm{mg} / \mathrm{kg}$, oral $)$ & $0.76 \pm 0.005^{*}$ & $6.11 \pm 0.02^{*}$ \\
\hline 5. & Test drugdose III & $\begin{array}{l}\text { CP }(200 \mathrm{mg} / \mathrm{kg}, \text { i.p. })+\text { Curcumin }+ \text { Quercetin } \\
(80 \mathrm{mg} / \mathrm{kg}+200 \mathrm{mg} / \mathrm{kg} \text {, oral })\end{array}$ & $0.71 \pm 0.007^{*}$ & $6.74 \pm 0.01^{*}$ \\
\hline
\end{tabular}

Statistically significance test was done by one-way ANOVA followed by Dennett's ' $t$ ' test using SPSS 16.0 Windows version. ${ }^{*} p<0.05$ compared to disease control group.

Table 5: Effects of curcumin and curcumin + quercetin on tissue MDA and serum MDA of different groups of animals

\begin{tabular}{|c|l|l|c|c|}
\hline Sl.No. & Groups & Treatment given & $\begin{array}{c}\text { Tissue MDA } \\
\text { levels }(\mathbf{n m o l} / \mathbf{g m}) \\
\text { Mean } \pm \text { SEM }\end{array}$ & $\begin{array}{c}\text { Serum } \\
\text { MDA }\left(\mathbf{1 0}^{3} \mathbf{m M}\right) \\
\text { Mean } \pm \text { SEM }\end{array}$ \\
\hline 1. & Naive control & Saline, oral & $93.30 \pm 0.12$ & $0.22 \pm 0.031$ \\
\hline 2. & Disease control & $\mathrm{CP}(200 \mathrm{mg} / \mathrm{kg}$, i.p) & $295.21 \pm 0.73$ & $0.47 \pm 0.062$ \\
\hline 3. & Test drug dose I & $\mathrm{CP}(200 \mathrm{mg} / \mathrm{kg}$, i.p. $)+$ Curcumin $(80 \mathrm{mg} / \mathrm{kg}$, oral $)$ & $167.61 \pm 0.35^{*}$ & $0.35 \pm 0.055^{*}$ \\
\hline 4. & Test drug dose II & $\mathrm{CP}(200 \mathrm{mg} / \mathrm{kg}$, i.p. $)+$ Quercetin $(200 \mathrm{mg} / \mathrm{kg}$, oral $)$ & $110.11 \pm 0.25^{*}$ & $0.28 \pm 0.033^{*}$ \\
\hline 5. & Test drug dose III & $\begin{array}{l}\text { CP }(200 \mathrm{mg} / \mathrm{kg}, \text { i.p. })+\text { Curcumin }+ \text { Quercetin } \\
(80 \mathrm{mg} / \mathrm{kg}+200 \mathrm{mg} / \mathrm{kg}, \text { oral })\end{array}$ & $102.12 \pm 0.15^{*}$ & $0.26 \pm 0.037^{*}$ \\
\hline
\end{tabular}

Statistically significance test was done by one-way ANOVA followed by Dennett's ' $t$ ' test using SPSS 16.0 Windows version. ${ }^{*} p<0.05$ compared to disease control group.

Table 6: Effects of curcumin and curcumin + quercetin on tissue GSH, Tissue GSSG on different animal groups

\begin{tabular}{|c|l|l|c|c|}
\hline SI.No. & Groups & Treatment given & $\begin{array}{c}\text { Tissue GSH } \\
\text { levels }(\mu \mathrm{g} / \mathbf{g m}) \\
\text { Mean } \pm \text { SEM }\end{array}$ & $\begin{array}{c}\text { Tissue GSSG } \\
\text { levels }(\mathrm{g} / \mathbf{g m}) \\
\text { Mean } \pm \text { SEM }\end{array}$ \\
\hline $\mathbf{1 .}$ & Naive control & Saline, oral & $9.44 \pm 0.72$ & $0.042 \pm 0.015$ \\
\hline $\mathbf{2}$. & Disease control & CP $(200 \mathrm{mg} / \mathrm{kg}$, i.p) & $3.11 \pm 0.18$ & $0.085 \pm 0.041$ \\
\hline $\mathbf{3}$. & Test drug dose I & CP $(200 \mathrm{mg} / \mathrm{kg}$, i.p. $)+$ Curcumin $(80 \mathrm{mg} / \mathrm{kg}$, oral $)$ & $5.88 \pm 0.43^{*}$ & $0.058 \pm .042^{*}$ \\
\hline $\mathbf{4 .}$ & Test drug dose II & CP $(200 \mathrm{mg} / \mathrm{kg}$, i.p. $)+$ Quercetin $(200 \mathrm{mg} / \mathrm{kg}$, oral $)$ & $8.52 \pm 0.69^{*}$ & $0.049 \pm 0.023^{*}$ \\
\hline $\mathbf{5 .}$ & Test drug dose III & $\begin{array}{l}\text { CP }(200 \mathrm{mg} / \mathrm{kg}, \text { i.p. })+\text { Curcumin }+ \text { Quercetin } \\
(80 \mathrm{mg} / \mathrm{kg}+200 \mathrm{mg} / \mathrm{kg} \text {, oral })\end{array}$ & $8.96 \pm 0.71^{*}$ & $0.047 \pm 0.034^{*}$ \\
\hline
\end{tabular}

Statistically significance test was done by one-way ANOVA followed by Dennett's 't' test using SPSS 16.0 Windows version. ${ }^{*} p<0.05$ compared to disease control group. 


\subsection{Tissue GSH and GSSG}

The Table 6 represents that the tissue GSH level was decreased while, GSSG was increased by cyclophosphamide treatment. The data showed that curcumin and curcumin + quercetin has significantly enhanced the decreased levels of tissue GSH and decreased GSSG.

\subsection{Histological studies}

The results of the histological analysis are seen in Figures 1. In contrast to controls, cyclophosphamide exposure causes histopathological modifications in rat hepatocytes, including increased mononuclear invasion, hemorrhage, and hepatocyte degeneration (necrosis). The liver tissue of rats given curcumin and curcumin + quercetin recovered well, with no necrosis or fatty deposition of hepatocytes.

\section{Discussion}

The main cause of hepatic injury is free radicals' formation which generated during the metabolism process of xenobiotic $(\mathrm{Gu}$ and Manautou, 2012). These free radicals basically cause the hepatic cell injury. Liver is the main site for the metabolism of most of xenobiotic, so that generation of free radical in liver is higher than other organs (Muriel, 2009). In this study, we used an overdose of CP to cause hepatic damage in the laboratory animals, a condition known as drug-induced hepatotoxicity. This is the most common form of drug-induced liver cell necrosis in cancer patients, with the damage limited to a small region of the liver lobule (Kleiner, 2017). It may show up as a very high ALT level and serious liver dysfunction, leading to acute liver failure (Giannini et al., 2015).
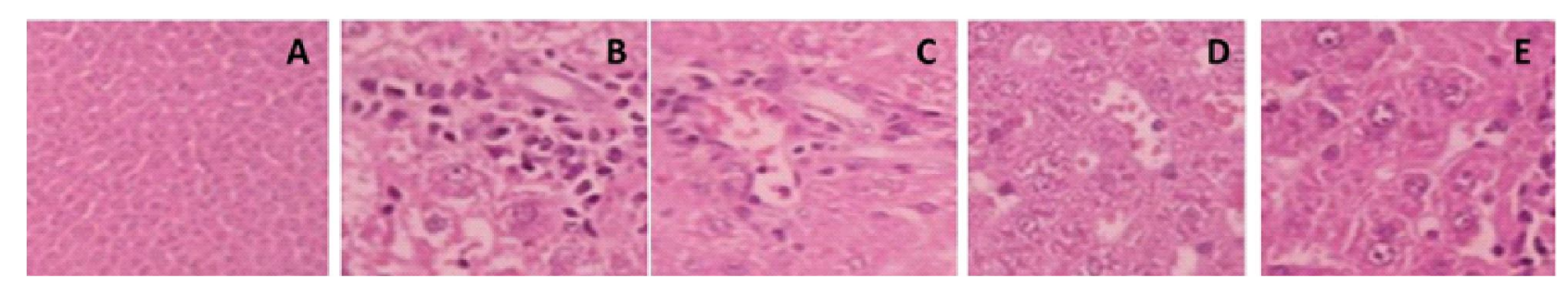

Figure 1: Histopathological images of liver section stained with haematoxylin and eosin-stained liver tissue: (A) Naive control, (B) Disease control, (C) Test drug dose I, (D) Test drug dose II and (E) Test drug dose III. (H and E X 400).

Alkylating agents cause tissue damage through generating lipid peroxidation. CP will alkylate and oxidize the intra cellular GSH and protein thiol groups, depleting the liver GSH pool in higher doses. So, it causes increased lipid peroxidation and ultimately, liver damage (Polavarapu et al., 1998). The GSH content in the CP-treated group was found to be greatly lower in this sample. Cyclophosphamideinduced liver toxicity necessitates the secretion of cytochrome P450 and/or the depletion of liver GSH (Grattagliano et al., 2009). GSH depletion can be caused by reactive metabolites conjugating with it, resulting in cellular necrosis (Hinson et al., 2010).

Curcumin and quercetin treatment restored GSH levels, highlighting their function in preventing cyclophosphamide induced hepatotoxicity. After CP administration, the level increased, but curcumin and quercetin treatment took it down to near normal levels. Except for globulins, protein metabolism is a large part of the liver's work, and a healthy functioning liver is needed for the synthesis of serum proteins. After CP injection, hypoproteinemia was found, but after curcumin and quercetin therapy, this returned to the normal.

Excessive heme damage and biliary tract blockage resulted in hyperbilirubinemia A. (Stillman et al., 1990). The mixture of curcumin and quercetin lowered bilirubin levels while increasing protein levels and provided safety. CP appears to interfere with lipoprotein synthesis and modify cholesterol metabolism. When CP-treated rats were compared to control, curcumin and quercetincombination-treated rats, cholesterol and triglyceride levels were substantially higher. The increased esterification of free fatty acids, reduced hepatic release of lipoprotein and increased supply of free fatty acids could all contribute to rise in the levels of triglyceride during cyclophospha-mide intoxication.
The combination of curcumin and quercetin greatly reduced serum lipid profile in rats suffering from CP toxicity. Control animals histological profiles revealed regular hepatocytes. The toxic control group's liver showed extreme acute congestion, hydropic degeneration, pyknosis, and intermittent necrosis in a segment. Curcumin and quercetin mixture treated animals' liver segments revealed normal hepatic architecture with few fatty globules. Curcumin and quercetin-treated animals liver segments only displayed normal hepatic cords and no serious congestion, pyknosis, or periodic necrosis, suggesting marked hepatocyte defence against CP-induced hepatic damage.

Hepatoprotection was shown by the absence of hepatic derangements and the preservation of the liver's cytoarchitecture. Functional parameters and serum marker enzyme levels have improved. Antioxidant parameters and histopathological studies showed that the curcumin and quercetin combination dose possesses hepatoprotective activity.

\section{Conclusion}

Animals with CP-induced hepatotoxicity have significant histopathological modifications throughout the cytoarchitecture of the liver. Humans with severe liver diseases exhibit the same behavior. In the current analysis, animals given a mixture of curcumin and quercetin had limited hepatic derangements and their cytoarchitecture remained unchanged, suggesting hepatoprotection. Functional parameters and serum marker enzyme levels have improved. The curcumin and quercetin mixture has hepatoprotective efficacy, according to antioxidant parameters and histopathological tests. 


\section{Acknowledgments}

The authors are thankful to the Pacific Academy of Higher Education and Research University for providing facilities, critical suggestion regarding the improvement of the manuscript.

\section{Conflict of interest}

The authors declare that there is no conflicts of interest relevant to this article.

\section{References}

Biswas, S.K.; Mc Clure, D.; Jimenez, L.A.; Megson, I. L. and Rahman, I. (2005) Curcumin induces glutathione biosynthesis and inhibits NF-kappa B activation and interleukin-8 release in alveolar epithelial cells: mechanism of free radical scavenging activity. Antioxid. Redox. Signal., 7:32-41.

Brown, G. T. and Kleiner, D. E. (2016). Histopathology of nonalcoholic fatty liver disease and nonalcoholic steatohepatitis. Metabolism., 65:10801086.

Cohly, H.H.; Taylor, A.; Angel, M.F. and Salahudeen, A.K. (1998). Effect of turmeric, turmerin and curcumin on $\mathrm{H}_{2} \mathrm{O}_{2}$-induced renal epithelial (LLC-PK1) cell injury. Free Radic. Biol. Med., 24:49-54.

Dal'Bó, G.A., Sampaio, F.G., Losekann, M.E., Queiroz, J.F.D., Luiz, A.J.B., Wolf, V.H.G., Gonçalves, V.T. and Carra, M.L. (2015). Hematological and morphometric blood value of four cultured species of economically important tropical foodfish. Neotropical. Ichthyology. (AHEAD).

Giannini, E.G., Testa, R., and Savarino, V. (2005). Liver enzyme alteration: a guide for clinicians. CMAJ., 172:367-379.

Grattagliano, I., Bonfrate, L., Diogo, C.V., Wang, H.H., Wang, D.Q. and Portincasa P. (2005). Biochemical mechanisms in drug-induced liver injury: certainties and doubts. World J. Gastroenterol., 15:4865-4876.

Grigorian, A. and O'Brien, C.B. (2014). Hepatotoxicity Secondary to Chemotherapy. J. Clin. Transl. Hepatol., 2:95-102.

Gu, X. and Manautou, J.E. (2012). Molecular mechanisms underlying chemical liver injury. Expert. Rev. Mol. Med., 14:e4.

Guntherberg, H. and Rost J. (1966). The true oxidized glutathione content of red blood cells obtained by new enzymic and paper chromatographic methods. Anal. Biochem., 15:205-210.

Hinson, J.A.; Roberts, D.W. and James, L.P. (2010). Mechanisms of acetaminophen-induced liver necrosis. Handb. Exp. Pharmacol., 196:369-405
Kleiner, D.E. (2017). Drug-induced Liver Injury: The Hepatic Pathologist's Approach. Gastroenterology Clinics of North America., 46:273296.

Liver Tox, (2019). Clinical and research information on drug-induced liver injury [internet]. National Institute of Diabetes and Digestive and Kidney Diseases; 2012- Sinusoidal Obstruction Syndrome (Veno-occlusive Disease).

Muriel, P. (2009). Role of free radicals in liver diseases. Hepat. Int., 3: 526536.

OECD (2001). OECD guidelines for the testing of chemicals, section 4, test No. 425: Acute oral toxicity up-and-down procedure. OECD Publishing.

Okada, K.; Wangpoengtrakul, C.; Tanaka, T.; Toyokuni, S.; Uchida, K. and Osawa, T. (2001). Curcumin and especially tetrahydrocurcumin ameliorate oxidative stress-induced renal injury in mice. J. Nutr., 131:20902095.

Polavarapu, R.; Spitz, D.R.; Sim, J.E.; Follansbee, M.H.; Oberley, L.W.; Rahemtulla, A. and Nanji, A.A. (1998). Increased lipid peroxidation and impaired antioxidant enzyme function is associated with pathological liver injury in experimental alcoholic liver disease in rats fed diets high in corn oil and fish oil. Hepatology., 27:1317-1323.

Sedlak, J. and Lindsay, R.H. (1968). Estimation of total, protein-bound, and nonprotein sulfhydryl groups in tissue with Ellman's reagent. Anal. Biochem., 25:192-205.

Senthilkumar, S. Devaki, T. Manohar, B.M. and Babu, M.S. (2006). Effect of squalene on cyclophosphamide-induced toxicity. Clinica. Chimica. Acta., 364:335-342.

Siddiqui, S.; Rashid Khan, M. and Siddiqui, W.A. (2010). Comparative hypoglycemic and nephroprotective effects of tocotrienol rich fraction (TRF) from palm oil and rice bran oil against hyperglycemia induced nephropathy in type 1 diabetic rats. Chemico-Biological Interactions, 188:651-658.

Sreejayan, and Rao, M.N. (1994). Curcuminoids as potent inhibitors of lipid peroxidation. Journal of Pharmacy and Pharmacology, 46:10131016.

Stillman, A.E. Jaundice, I.N.; Walker, H.K.; Hall, W.D. and Hurst, J.W. (1990). Clinical methods: The history, physical, and laboratory examinations. 3rd edition. Boston: Butterworths., pp: 87.

Subramaniam, S.R.; Cader, R.A.; Mohd, R.; Yen, K.W. and Ghafor, H.A. (2013). Low-dose cyclophosphamide-induced acute hepatotoxicity. Am J Case Rep., 14:345-349.

Manoj Kumar Yadav, Jayesh Dwivedi, Prabhat Kumar Upadhyay and Vishal Kumar Vishwakarma (2021). The 